\title{
JUURNAL.RU
}

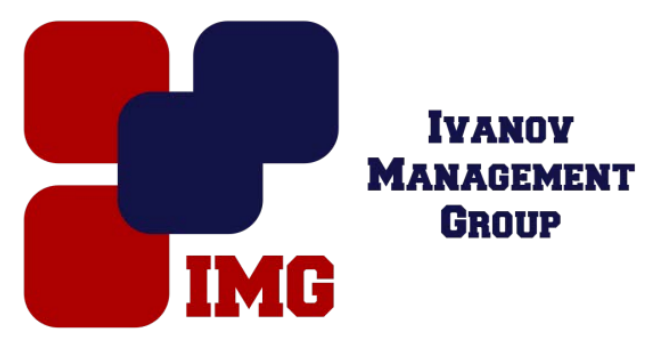

Герасимов С.В., Викулова М.А., Горшков Н.В., Костин К.Б., Шумилин А.И., Пичхидзе С.Я. СГТУ им. Ю. А. Гагарина Саратов, Россия

doi: 10.18411/lj-31-03-2017-2-10

idsp 000001:1j-31-03-2017-2-10

\section{Модернизация конструкции коленного артикулирующего вкладыша}

Известно, что при тотальном эндопротезировании коленного сустава в качестве материала для артикулирующего вкладыша обычно применяется сверхвысокомолекулярный полиэтилен (СВМПЭ). Однако наличие вкладыша из этого материала может привести к появлению продуктов износа полиэтилена, что ведет к остеолизу костей, образующих коленный сустав.

Цель работы: усовершенствование конструкции артикулирующего вкладыша коленного сустава, увеличение срока его эксплуатации, ограничение выброса в кровь продуктов распада и получение эмпирических выводов о полезности предложенной технологии.

Предлагается нанесение на трущуюся поверхность вкладыша оксида алюминия Al2O3 методом магнетронного напыления.

Методика эксперимента. На образцы из СВМПЭ наносили Al2O3 с помощью магнетронно-распылительной системы на основе вакуумного универсального поста ВУП-4 в аргонокислородной плазме тлеющего разряда с пропорцией газов 1:1. Время осаждения пленки оксида алюминия составляло 20 мин., давление в камере порядка 2 Па. В качестве катода использовался $\mathrm{Al}$, толщина нанесенного покрытия $\mathrm{Al} 2 \mathrm{O} 3$ составила 45 нм.

При нанесении Al2O3 происходит плотное укрывание поверхности СВМПЭ, рис.1е. По данным РФА при модификации поверхности СВМПЭ возрастает концентрация Al2O3, рис.1ж. В процессе модельного износа вкладыша на машине трения МТ-2 в течение одного часа при 60 обор/мин. происходит образование каверн и разглаживание поверхности СВМПЭ, при 
уменьшении концентрации Al2O3 в поверхностном слое. Износостойкость вкладыша повышается на 10\%. На боковую поверхность вкладыша наносится цинк-гидроксиапатит Zn-ГА для создания антимикробного эффекта, рис.13.

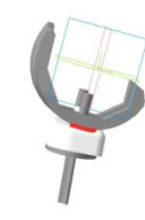

$a$

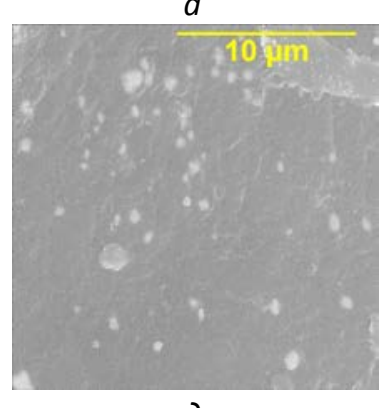

$\partial$

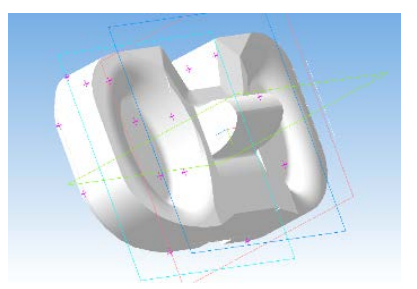

6

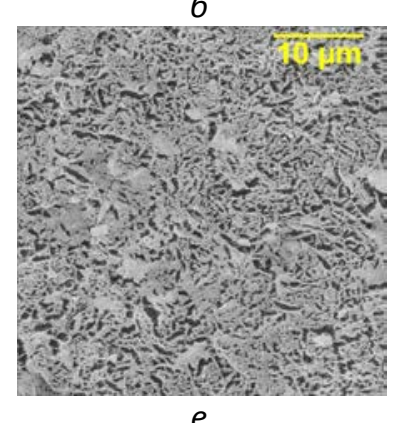

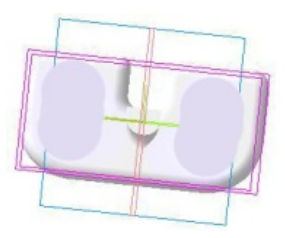

B

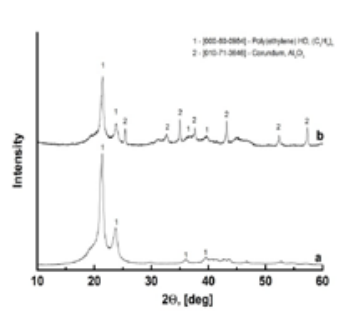

HC

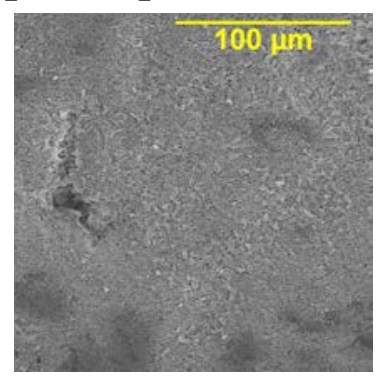

2

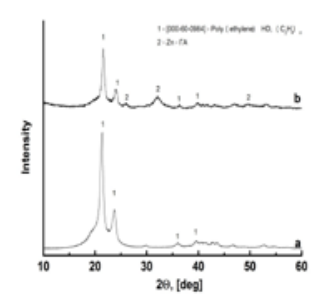

3

Рис.1. Вкладыш СВМПЭ, где: $а$ - общий вид протеза, б - вкладыш, в - область напыления, г, д - СВМПЭ после износа, е - СВМПЭ после напыления Al2O3, ж - РФА СВМПЭ + Al2O3, з - РФА СВМПЭ + Zn-ГA

Выводы: показано, что в результате магнетронного напыления Al2O3 на поверхность СВМПЭ износостойкость повышается на 10\% при сохранении вязкой сердцевины, что поможет избежать выброса в кровь токсичных веществ.

\section{Литература}

1. Эндопротезы крупных суставов: каталог / Джонсон \& Джонсон, 2012.-104 с.

2. Белякова О.В., Перинская И.В., Пичхидзе С.Я. Биосовместимое антимикробное покрытие эндопротеза коленного сустава. Самара: Л-Журнал, 2016. - 2c.

3. Сенатов Ф.С. Микроструктура и свойства композитов медицинского назначения на основе СВМПЭ. Автореф. ...канд. техн. наук, М.: МИСиС, 2013. - 24c.

4. Герасимов С.В., Мамбетова А.И., Шарыпова Е.А., Костин К.Б., Шумилин А.И., Шпиняк С.П., Пичхидзе С.Я. Модернизация конструкции коленного эндопротеза. Самара: Л-Журнал, 2016. - 2c.

5. Костин К.Б., Шумилин А.И., Шпиняк С.П., Кошуро В.А., Родионов И.В., Пичхидзе С.Я. Усовершенствование конструкции коленного эндопротеза. Prospects of world science-2016. Materials of the XII international scientific and practical conference. Sheffield. 2016.-P.8-10.

6. Шумилин А.И., Шпиняк С.П., Пичхидзе С.Я. К вопросу повышения износостойкости вкладыша коленного эндопротеза. Саратов: СГУ, 2016. - 3c. 